DE

M E D I C I N A

T R O P I C A L

$\mathrm{DE}$

S ÃO PAULO

JOURNAL OF THE SÃO PAULO INSTITUTE OF TROPICAL MEDICINE

${ }^{1}$ Fundação Oswaldo Cruz, Escritório Técnico Regional, Teresina, Piauí, Brazil

${ }^{2}$ Fundação Oswaldo Cruz, Escola Nacional de Saúde Pública, Departamento de Epidemiologia em Saúde Pública, Rio de Janeiro, Rio de Janeiro, Brazil

${ }^{3}$ Secretaria de Saúde do Estado do Piauí, Teresina, Piauí, Brazi

${ }^{4}$ Fundação Oswaldo Cruz, Instituto Oswaldo Cruz, Laboratório de Epidemiologia e Sistemática Molecular, Rio de Janeiro, Rio de Janeiro, Brazil

${ }^{5}$ Fundação Oswaldo Cruz, Instituto Oswaldo Cruz, Laboratório Interdisciplinar de Vigilância Entomológica em Diptera e Hemiptera, Rio de Janeiro, Rio de Janeiro, Brazil

${ }^{6}$ Universidade Iguaçu, Nova Iguaçu, Rio de Janeiro, Brazil

Correspondence to: Jéssica Pereira dos Santos

Fundação Oswaldo Cruz, Escritório Técnico Regional, Rua Magalhães Filho, 519, CEP 64000-128, Centro/Norte, Teresina, PI, Brazil

Tel: +55 86 3326-2100.

E-mail: jessik_ssantos@hotmail.com

Received: 13 February 2020

Accepted: 21 July 2020

\section{Spatial distribution of synanthropic triatomines in Piaui State, Northeastern Brazil}

\author{
Jessica Pereira dos Santos ${ }^{(1)}$, Lucas Melo Guimarães², Inácio Pereira Lima ${ }^{3}$, \\ Francisca Miriane de Araújo Batista ${ }^{\left({ }^{3}\right.}$, Filipe Anibal Carvalho-Costa ${ }^{1,4}$, \\ Jacenir Reis dos Santos- Mallet ${ }^{1,5,6}$
}

\section{ABSTRACT}

This study aimed to describe the spatial distribution and assess entomological indicators of synanthropic triatomines in Piaui State, Northeastern Brazil. We used surveillance data on the detection, identification and assessment of natural infection with trypanosomatids from triatomines in the State from 2014 to 2017. The State was divided into four macroregions. In relation to the dispersion rates of triatomines, they were much lower in the North, when compared to Southwest, Southeast and Central North macroregions. Infestation rates were higher in the Southwest and Southeast and intradomicile infestation rates varied during the study period, reaching high values in all regions. Insects belonging to the species Triatoma brasiliensis complex, Triatoma pseudomaculata, Triatoma sordida, and to the genus Panstrongylus spp. and Rhodnius spp. were collected during this period. T. brasiliensis was collected from all four regions of the State, but more frequently in those located in the Southeast. A similar pattern was observed for T. pseudomaculata. T. sordida was detected in the municipalities in the Southeast and Southwest regions, and less frequently in the Central North municipalities. Rhodnius spp. was detected in the Central North and North regions, and Panstrongylus spp. in the Central North and Southeast regions. The highest trypanosomatid-positivity rate of T. brasiliensis and Panstrongylus spp. was in the Southeast region. A significant proportion of the municipalities of Piaui State presents entomological parameters that indicate a risk of Chagas disease by vector transmission.

KEYWORDS: Chagas disease. Spatial distribution. Triatomines. Piaui State.

\section{INTRODUCTION}

Chagas disease (American trypanosomiasis) is caused by the protozoan Trypanosoma cruzi. This organism circulates enzootically in nature, transmitted among sylvatic and domestic mammals by hematophagous insects of the subfamily Triatominae ${ }^{1}$. When triatomines feed on humans they can transmit T. cruzi, which is shed in their feces shortly after bloodsucking. The various species of triatomines occupy specific geographic distributions, defined in part by their natural habitats within different regions and biomes on the American continent ${ }^{2-7}$. Distinct species of triatomines transmit $T$. cruzi with varying efficiency, defined by the insects' behavior, physiology and adaptation to the human domicile ${ }^{8-11}$. After an intensive utilization of pyrethroid insecticides in endemic areas in Brazil, the transmission of Chagas disease by triatomines (mainly Triatoma infestans) was virtually eliminated in many States $^{12}$. In 2006, Brazil received the Certificate of Interruption of Transmission of Chagas Disease by Triatoma infestans by the Pan American Health Organization/ 
World Health Organization ${ }^{13}$. This was possible due to the virtual inexistence of wild stocks of $T$. infestans, which was introduced in Brazil (non-autochthonous) and, consequently, was restricted to domestic and peridomestic environments ${ }^{14,15}$. Nevertheless, this is not the situation of Northeastern Brazil, where surveillance activities need to be maintained after control efforts, since T. cruzi transmitters are native and consequently have wild environments as their natural habitat ${ }^{16}$. The region presents a worrying situation because it contains the highest prevalence of secondary vectors involved in the transmission of the disease. In particular, it contains the dispersion epicenter of two species that are difficult to control by the routine methods recommended by the National Health Foundation, Triatoma brasiliensis and Triatoma pseudomaculata. Here, a high proportion of the rural population lives in precarious housing conditions and there is a low level of operational coverage in the Chagas disease control program ${ }^{17}$.

Studies of Chagas disease in Piaui State began in 1916, with the identification of individuals presenting with megaesophagus and heart disease, in addition to the occurrence of four species of triatomines in the municipalities of Sao Raimundo Nonato, Parnagua and Corrente ${ }^{18}$. In 1975, the first autochthonous cases of Chagas disease with cardiac and digestive manifestations were reported in the municipalities of Oeiras, Castelo do Piaui and Bom Jesus do Gurgueia ${ }^{19}$. Data from the first national Chagas disease serological survey, performed between 1975 and 1980, showed that Piaui was among the six Brazilian States with a global seroprevalence rate of Chagas disease above $4 \%$, with involvement of all age groups ${ }^{20}$. In the same period, it was demonstrated that the municipality of Oeiras was considered an area of active transmission due to the presence of domiciliary triatomines infected with T. cruzi, and children under 5 years old presenting positive serology for the disease ${ }^{21}$. In addition to this study, several others were carried out showing both, the distribution and the seropositivity of triatomines in the State ${ }^{22-26}$.

Between 1996 and 1997, in conjunction with active control programs, a serological survey with school-aged children registered a significantly lower prevalence rate and pointed to a substantial decrease in transmission ${ }^{27}$. In 2002, a new State-based serological survey was carried out, including 36,399 people living in rural areas across 216 municipalities. This study, which estimated a prevalence rate of $1.9 \%$, ranging from $0.1 \%$ in children under 4 years of age to $6.5 \%$ in people aged 60 to 69 years, demonstrated the heterogeneity of the spatial distribution of the disease in Piaui State. In this way, the municipalities belonging to the health districts based in Oeiras, Sao Joao do Piaui and Picos had the highest positivity rates, ranging from $4.3 \%$ to
$5.3 \%{ }^{28}$. These regions are located in the Caatinga biome of the semiarid region in the Southeast of the state. This work aimed to describe the current spatial distribution and assess entomological indicators of vectors of Trypanosoma cruzi infection in Piaui State, through the collection of the most recent data generated by the entomological surveillance system of the State.

\section{MATERIAL AND METHODS}

\section{Description of the study area}

The Piaui State is located between $2^{\circ} 44^{\prime} 49^{\prime \prime}$ and $10^{\circ} 55^{\prime} 05^{\prime}$ 'South and between $40^{\circ} 22^{\prime} 12^{\prime \prime}$ ' and $45^{\circ} 59^{\prime}$ 'West. According to $\mathrm{IBGE}^{29}$, the State has an estimated population of 3,273,227 people, occupying an area of $251,529 \mathrm{~km}^{2}$, divided into 224 municipalities and bounded by the states of Ceara and Pernambuco to the East, Bahia to the South and Southeast, Tocantins to the Southwest and Maranhao to the West. It presents a typical tropical climate with high average temperatures ranging from $18{ }^{\circ} \mathrm{C}$ to $39{ }^{\circ} \mathrm{C}$ and relative humidity ranging from $60 \%$ to $86 \%$. The State is divided into four main regions: North, Central North, Southwest and Southeast (Figure 1). The Piaui State presents a confluence of three Brazilian biomes. In the East and Southeast of the State, semi-arid landscapes predominate in the Caatinga biome and, in the Southwest, the Cerrado vegetation predominates. To the West, along the border with the State of Maranhao, an extensive ecotonal area is represented by the Mata de Cocais, where palm trees of different species abound ${ }^{30,31}$.

\section{Entomological surveillance}

Currently, the control of Chagas disease has been guided by entomological surveillance actions and focal interventions with insecticides. Active surveillance is coordinated by agents in a decentralized manner, managed by the municipal administration under the supervision of the State Health Secretariat. Surveillance information is centralized in a database called the Field Operations Information System - Chagas/Piaui. In the field, surveillance actions involve home visits in which houses are inspected in detail by insect-seeking agents, both inside the dwellings and peridomestic structures, such as pens, poultry houses and backyards. In the Piaui State, the captured insects are sent to a laboratory and identified at the species level, in addition to having their intestinal contents examined by light microscopy to evaluate the presence of flagellate protozoa (trypanosomatids). For the present study, specimens belonging to different species of the genera Panstrongylus spp. and Rhodnius spp. were grouped within the respective 


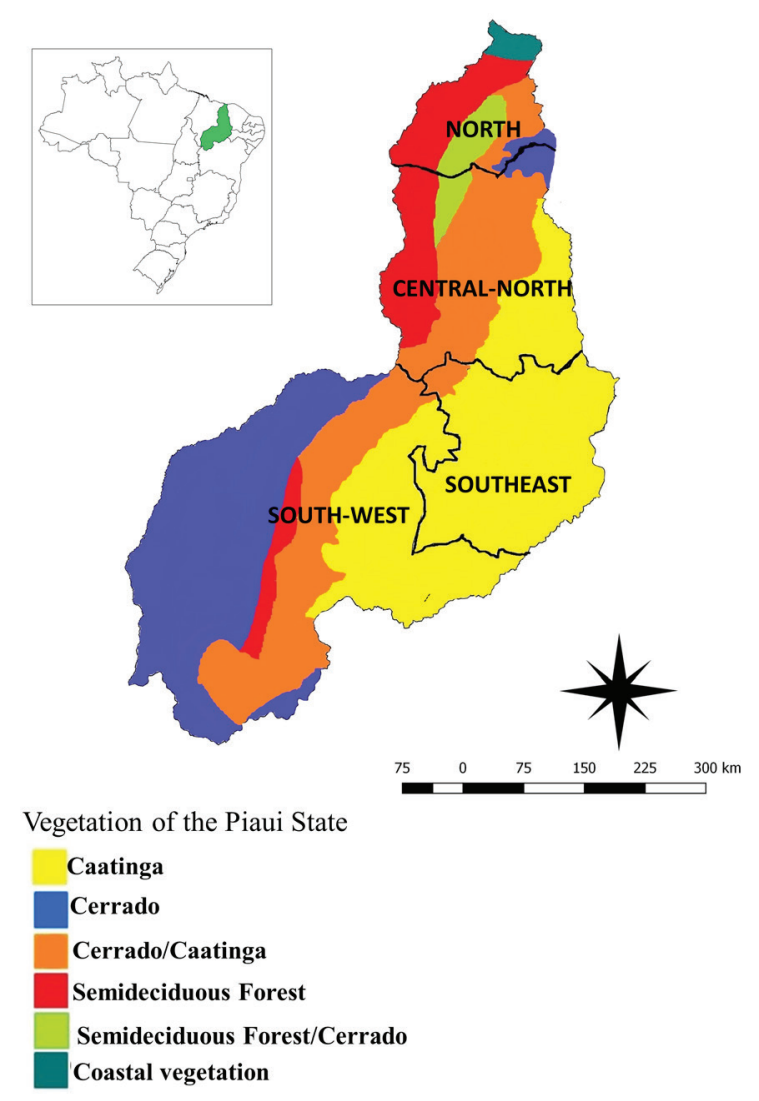

Figure 1 - Map of Piaui State with the division of regions and type of vegetation.

genera due to the possibility of misidentifications at the species level by the local entomological surveillance technicians. This strategy was chosen after preanalytical procedures have identified some inconsistencies in the database, with the presence of Panstrongylus spp. and Rhodnius spp. species not yet described in the state. Thus, as these specimens were no longer available for reidentification by specialists, it was decided to consider only the genus.

Each municipality can choose whether or not to carry out the entomological surveillance activities of Chagas disease, and the municipality can also establish the coverage of activities in its territory. In this way, some municipalities did not carry out surveillance and therefore did not provide data for the system.

\section{Ecological and geospatial analysis}

We used the entomological monitoring data that includes information on capture, identification and assessment of natural infections with trypanosomatids of triatomines in the 224 municipalities in Piaui State during the period 2014 to 2017. The following variables for each municipality were assessed: (i) State region (categorized as North $[\mathrm{n}=32$ municipalities], Central North [n=64], Southeast [n=66] and Southwest [n=62]), (ii) presence of T. brasiliensis, T. pseudomaculata, T. sordida, Panstrongylus spp., and/or Rhodnius spp., (iii) rate of entomological surveillance coverage (number of locations evaluated/ total locations $\times 100$ ), (iv) rate of dispersion (number of localities with triatomines/ total evaluated localities $\mathrm{x} 100)$, (v) rate of infestation (number of houses with triatomines/total houses evaluated x 100), (vi) rate of intradomiciliary infestation $^{32}$ (number of households with intradomiciliary insects/ total houses evaluated x 100), (vii) absolute number of adult insects of each species collected in the intradomicile and the peridomicile, (viii) absolute number of nymphal instar insects of each species collected in the intradomicile and the peridomicile, (ix) number of trypanosomatid-infected triatomines (number of triatomines infected by trypanosomatids of each species collected in the intradomicile and the peridomicile), and (x) rate of natural infection by trypanosomatids (number of positive triatomines/ total triatomines examined $x$ 100). The analytical strategy was to compare the entomological indicators from each year in the four regions of the State, seeking differences in the spatial distribution of the various vector species of Trypanosoma cruzi infection. The data were made available by the municipalities. From these, thematic maps were prepared with the rates of surveillance coverage, dispersion rate, infestation rate and colonization rate, for each year of the historical series. Analyzing the number of insects and the number of infected insects, the centroids of each municipality with surveillance activities were used to plot pie charts with insect counts for each municipality and, through a Kernel (Bipedal quarry with radius 30,000 units of the layer) function, calculate the hot areas for each vector in the Piaui State, over the range of years of the study. The QGIS software was used for the analyzes, with the Coordinate Reference System EPSG: 4326 - WGS 84. The cartographic bases were obtained from the Brazilian Institute of Geography and Statistics.

\section{RESULTS}

Entomological indicators of vectors of Trypanosoma cruzi infection in Piaui State, 2014 - 2017

Among the 224 municipalities in Piaui State, the proportion that registered surveillance activities in some year between 2014 and 2017 was 10/32 [31.3\%] in the North, 23/64 [35.9\%] in the Central North, 61/66 [92.4\%] in the Southeast and 43/62 [69.4\%] in the Southwest regions. The spatial variation of the entomological indicators in the State from 2014 to 2017 can be seen in Figure 2 and 
Table 1. Regarding the coverage of surveillance actions of the vectors of Chagas disease, it can be observed that the highest rates are those of the municipalities of the Central North, Southeast and Southwest regions along the borders with the states of Ceara, Pernambuco and Bahia, in an area located in the East of the State. In relation to the dispersion rates of triatomines, they were much lower in the North, when compared to Southwest, Southeast and Central North regions. Infestation rates were higher in the Southwest and
Southeast and intradomicile infestation rates varied during the study period, reaching high values in all regions.

Spatial distribution of distinct vector species of Trypanosoma cruzi infection in Piaui State, 2014 2017

Insects belonging to the species $T$. brasiliensis complex, T. pseudomaculata, T. sordida, Panstrongylus spp. and

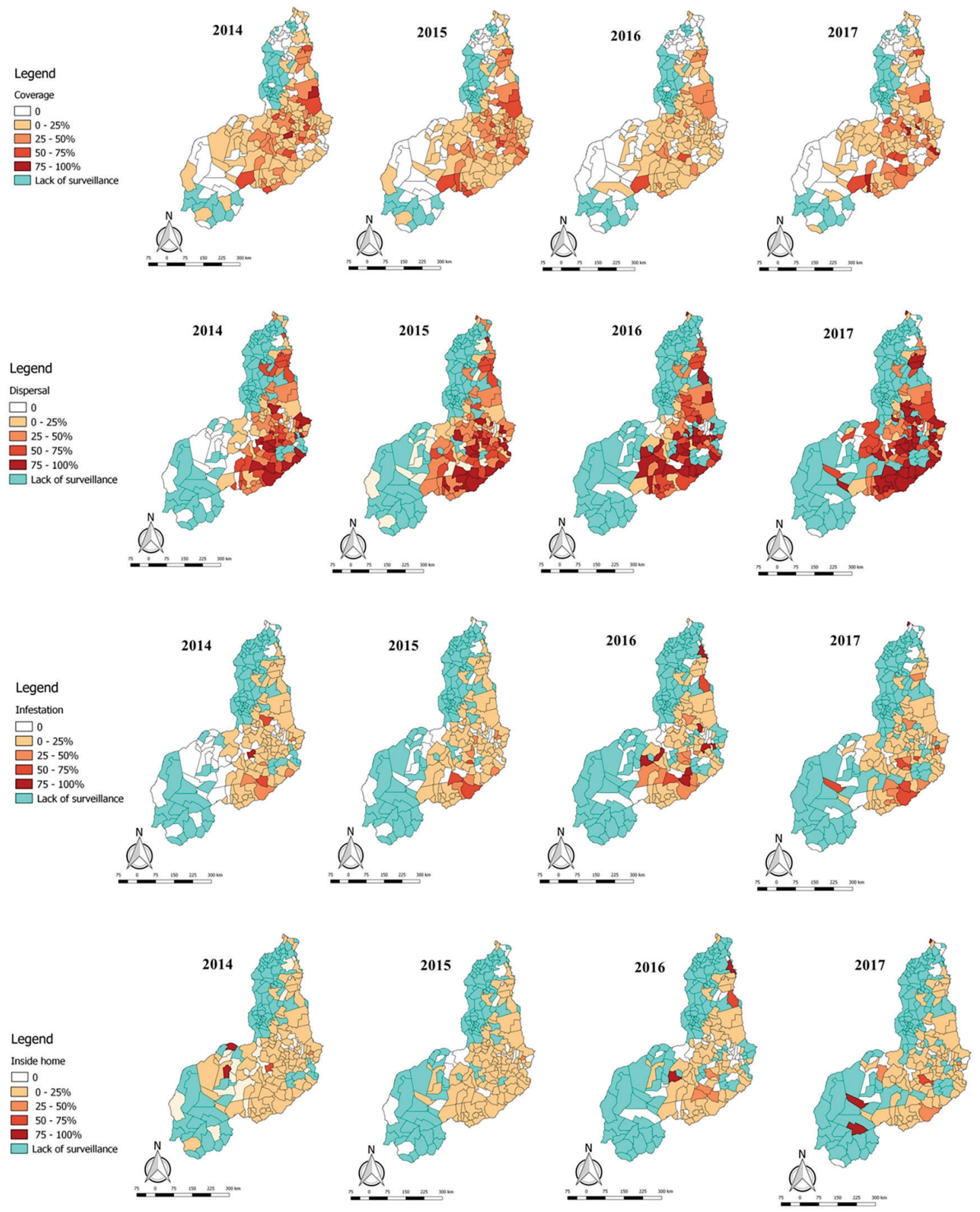

Figure 2 - Spatial variation of the entomological indicators in Piaui State in the years 2014 to 2017. 
Table 1 - Entomological indicators of Chagas disease vectors in the Piaui State, $2014-2017$.

\begin{tabular}{|c|c|c|c|c|}
\hline & $\begin{array}{l}\text { Mean } \pm \text { SD (range) of } \\
\text { coverage rates in the } \\
\text { municipalities, } \\
\text { expressed in } \%^{1}\end{array}$ & $\begin{array}{l}\text { Mean } \pm \text { SD (range) of } \\
\text { dispersal rates in the } \\
\text { municipalities, } \\
\text { expressed in } \%^{2}\end{array}$ & $\begin{array}{l}\text { Mean } \pm \text { SD (range) of } \\
\text { infestation rates in the } \\
\text { municipalities, } \\
\text { expressed in } \%^{3}\end{array}$ & $\begin{array}{c}\text { Mean } \pm \text { SD (range) } \\
\text { of intradomiciliary } \\
\text { infestation rates in the } \\
\text { municipalities, } \\
\text { expressed in } \%^{4}\end{array}$ \\
\hline \multicolumn{5}{|l|}{ Year/Region } \\
\hline \multicolumn{5}{|l|}{2014} \\
\hline Central North & $15.6 \pm 31.2(0-100)$ & $14.5 \pm 23.2(0-83)$ & $3.1 \pm 7.8(0-54)$ & $2.3 \pm 3.5(0-12)$ \\
\hline North & $10 \pm 24.8(0-80)$ & $6.1 \pm 14.8(0-66)$ & $0.1 \pm 0.3(0-1)$ & $0.4 \pm 0.4(0-1)$ \\
\hline Southeast & $48.2 \pm 34.1(0-100)$ & $42.7 \pm 32.9(0-100)$ & $8.6 \pm 11.5(0-54)$ & $4.1 \pm 5.8(0-32)$ \\
\hline Southwest & $28.1 \pm 34.4(0-100)$ & $14.6 \pm 25.7(0-100)$ & $3.8 \pm 13.6(0-100)$ & $6.6 \pm 17.9(0-100)$ \\
\hline \multicolumn{5}{|l|}{2015} \\
\hline Central North & $19 \pm 35.3(0-100)$ & $13.3 \pm 22.6(0-100)$ & $2.3 \pm 4.5(0-20)$ & $2.1 \pm 2.9(0-9)$ \\
\hline North & $15.1 \pm 33.2(0-100)$ & $9.1 \pm 22.9(0-100)$ & $0.8 \pm 2.4(0-9)$ & $2.4 \pm 2.9(0-6)$ \\
\hline Southeast & $42 \pm 36.3(0-100)$ & $43.4 \pm 33.3(0-100)$ & $10.1 \pm 13.1(0-62)$ & $4.6 \pm 6.3(0-31)$ \\
\hline Southwest & $29.4 \pm 39.4(0-100)$ & $18.3 \pm 29.9(0-100)$ & $3.7 \pm 9.6(0-62)$ & $3.6 \pm 5.4(0-24)$ \\
\hline \multicolumn{5}{|l|}{2016} \\
\hline Central North & $17.6 \pm 35.7(0-100)$ & $16.7 \pm 26.5(0-100)$ & $3.5 \pm 8.8(0-59)$ & $4.1 \pm 11.6(0-59)$ \\
\hline North & $6.4 \pm 24.9(0-100)$ & $6.4 \pm 21.9(0-100)$ & $2.8 \pm 13.9(0-78)$ & $21.3 \pm 40.3(0-92)$ \\
\hline Southeast & $19.4 \pm 31.8(0-100)$ & $36.7 \pm 39.5(0-100)$ & $11.6 \pm 20.6(0-100)$ & $5.3 \pm 9.7(0-39)$ \\
\hline Southwest & $10.5 \pm 24.4(0-100)$ & $17.6 \pm 30.1(0-100)$ & $7.2 \pm 19(0-100)$ & $7.9 \pm 17.8(0-92)$ \\
\hline \multicolumn{5}{|l|}{2017} \\
\hline Central North & $12.9 \pm 30.8(0-100)$ & $14.1 \pm 25.8(-83)$ & $2.6 \pm 6.1(0-31)$ & $2.1 \pm 2.6(0-10)$ \\
\hline North & $3.2 \pm 17.9(0-98)$ & $5.1 \pm 18.7(0-100)$ & $0.2 \pm 0.9(0-5)$ & $14.8 \pm 33.6(0-83)$ \\
\hline Southeast & $44 \pm 41.1(0-100)$ & $51.6 \pm 36.4(0-100)$ & $12.5 \pm 15.4(0-68)$ & $6.1 \pm 9.2(0-55)$ \\
\hline Southwest & $12.8 \pm 27.2(0-100)$ & $23.3 \pm 32(0-100)$ & $6.5 \pm 13.2(0-70)$ & $11.9 \pm 24.3(0-100)$ \\
\hline
\end{tabular}

The values represent the means \pm standard deviations (SD) and the range of the rates, expressed in \% in the municipalities belonging to each region of the state in the evaluated years: ${ }^{1}$ number of locations evaluated in the municipality / total locations in the locality $\times 100$; ${ }^{2}$ number of localities with triatomines / total evaluated localities $\times 100 ;{ }^{3}$ number of houses with triatomines / total houses evaluated x 100; ${ }^{4}$ number of houses with intradomiciliary triatomines / total houses evaluated $\times 100$.

Rhodnius spp. were collected. T. brasiliensis was collected in municipalities of all four regions of the State, but more frequently in those located in the Southeast (Figure 3). In this region, T. brasiliensis was present in $44 \%-73 \%$ of the municipalities during the study period. In the Central North and Southwest regions, the proportion of municipalities that were positive for T. brasiliensis ranged from $20 \%$ to $30 \%$. A similar pattern was observed for T. pseudomaculata, which was identified in $40 \%$ to $50 \%$ of the municipalities in the Southeastern region of Piaui State between 2014 and 2017 , and between $20 \%$ and $30 \%$ of the municipalities in the Central North and Southwest regions. A different pattern was identified for T. sordida, which was detected in $9 \%$ to $16 \%$ of the municipalities in the Southeast and Southwest regions in different years, and in less than $7 \%$ in the Central North municipalities. Also different was the geographic distribution of Rhodnius spp. detected from 2014 to 2017 in $7 \%$ to $15 \%$ of the Central North municipalities, up to $9 \%$ of the Northern municipalities, and was almost undetected in the Southeast and Southwest regions. Panstrongylus spp. was detected in the Central North regions (14\% of municipalities in 2015) and Southeast (18\% of municipalities in 2017). There is a heterogeneous geographic distribution of the different vector species of Trypanosoma cruzi infection in Piaui State (Figure 4). The predominance of $T$. brasiliensis can be observed in the North, Central North, Southeast and Southwest regions, whereas T. sordida is most frequently detected in the Central North, Southeast and Southwest regions. T. pseudomaculata and Panstrongylus spp. present hotspots in North, Central North, Southeast and Southwest regions. It may be noted that Rhodnius spp. was most frequently captured in the North and Central North regions. The mean number of specimens (including the developmental stage) collected 

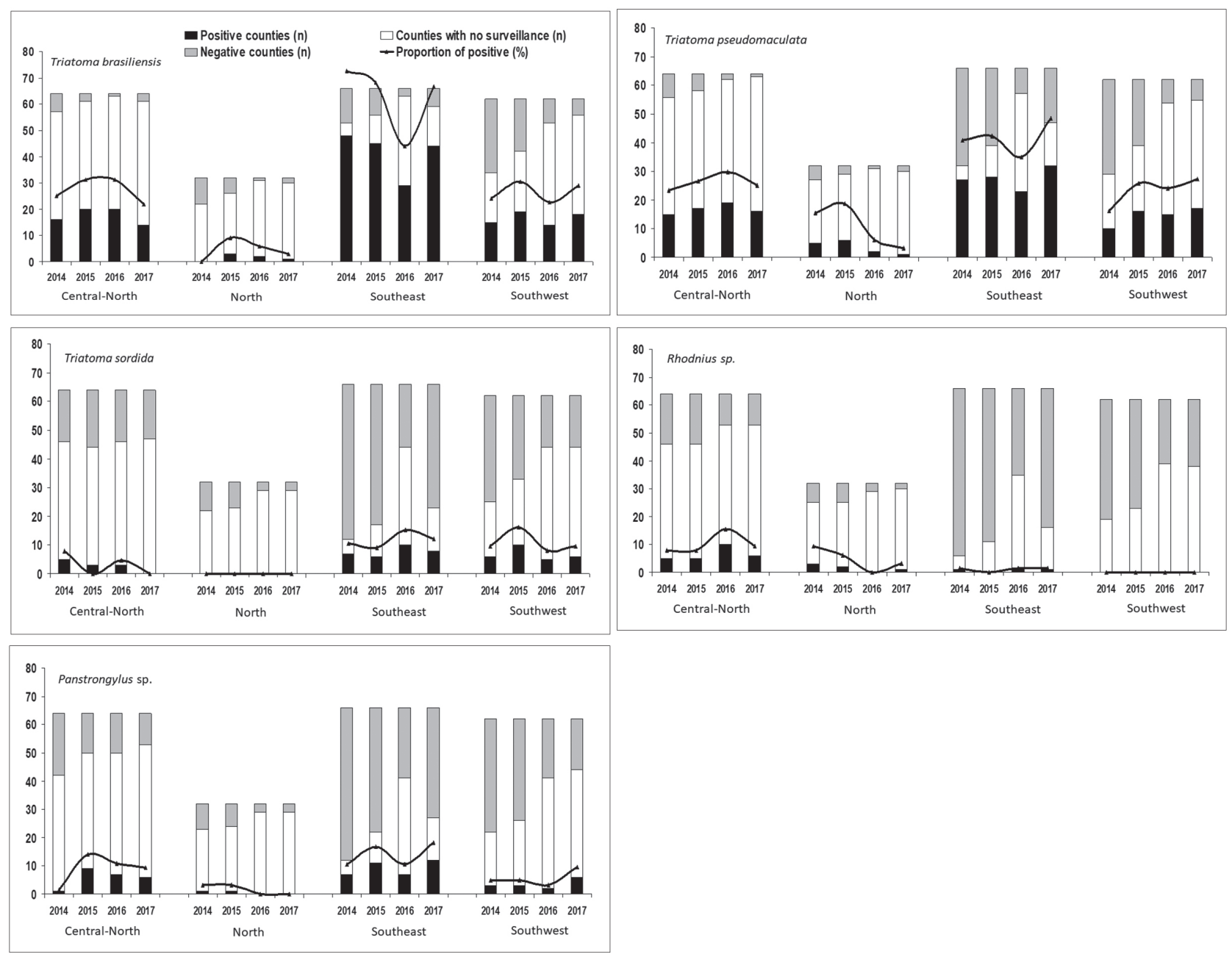

Figure 3 - Distribution of triatomines in Piaui State by species, year and region, during the period from 2014 to 2017.

in the different regions of the State in the period studied is shown in Table 2. The mean number of specimens of T. brasiliensis from the municipalities was higher in the Southeast region of the State, considering specimens of all stages and places of capture (adults inside houses, nymphs inside houses, adults in the peridomicile and nymphs in the peridomicile). For T. pseudomaculata, the Central North and Southwest regions had the highest mean numbers. T. sordida was captured far more frequently in the Southwest region of the State and Rhodnius spp., in the Central North followed by the North region. Panstrongylus spp. was collected more frequently in the Central North region.

\section{Trypanosomatid infection rates in vectors of Chagas disease in the Piaui State}

The geographic distribution of trypanosomatid-positive triatomines can be seen on the maps shown in (Figure 5). The occurrence of T. brasiliensis positive for trypanosomatids in the North, Central North, Southeast and Southwest regions, with a higher proportion of positive insects captured in the Southeast, can be observed. T. sordida was more frequently captured in Southeast and Southwest regions, with a predominance of positive insects in the Southwest region. T. pseudomaculata was captured more frequently in the North, Central North, Southeast and Southwest regions, with a predominance of positive insects in the Central North region. Infected Panstrongylus spp. were frequently captured in the North, Central North, Southeast and Southwest regions, with the highest proportion recorded in the Southwest. It can be observed that infected Rhodnius spp. were more frequently captured in the North and Central North regions, with emphasis on the Central North region, which presented the highest proportion of infected insects. Table 3 shows the positivity rates for trypanosomatids by region, species, stage and site of capture of the triatomines (inside houses or in the peridomestic environment). The highest positivity rate of $T$. brasiliensis and Panstrongylus spp. was found in the Southeast region, T. pseudomaculata and Rhodnius spp. in the Central North region and T. sordida 

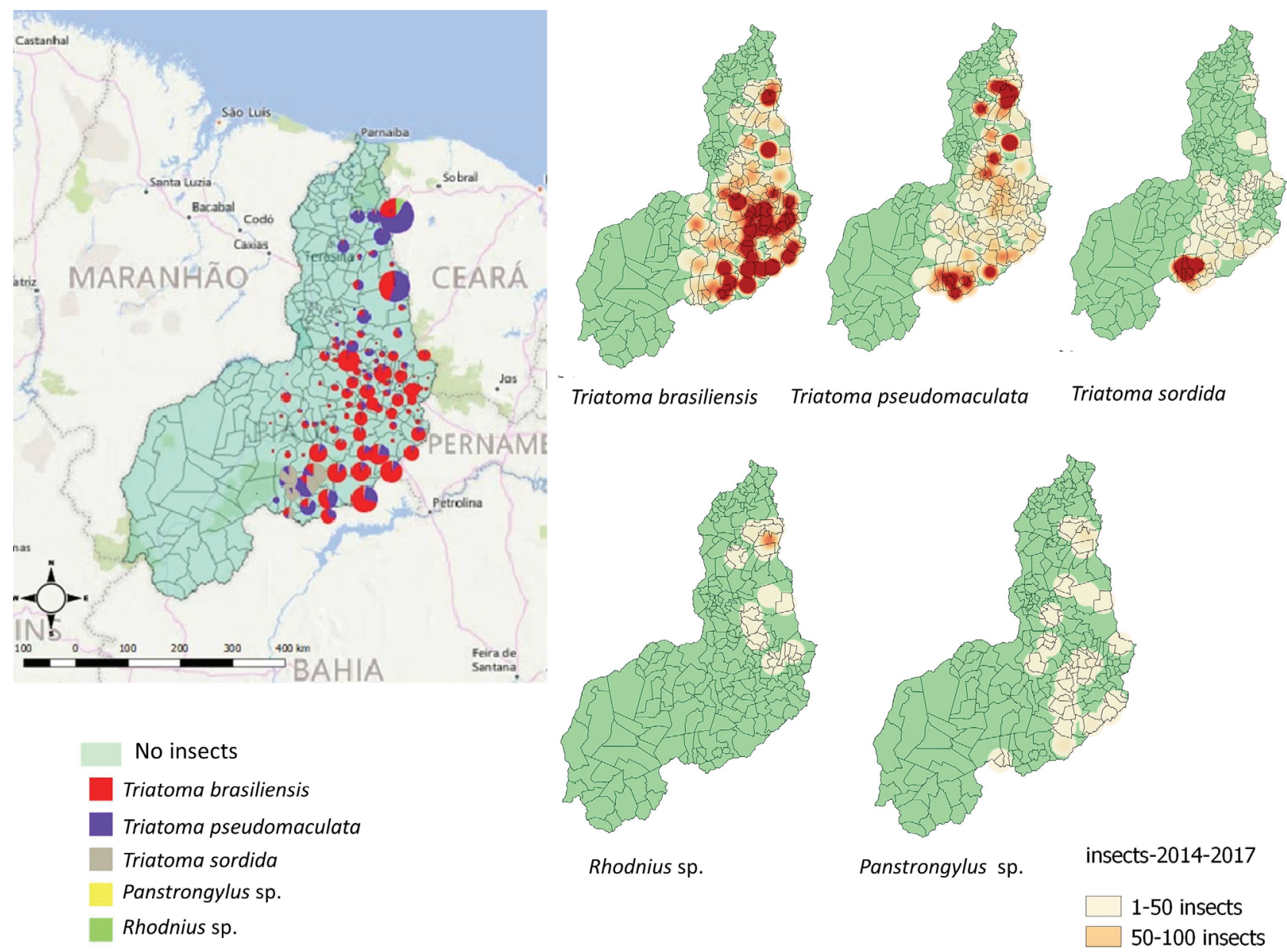

Triatoma brasiliensis Triatoma pseudomaculata Triatoma sordida

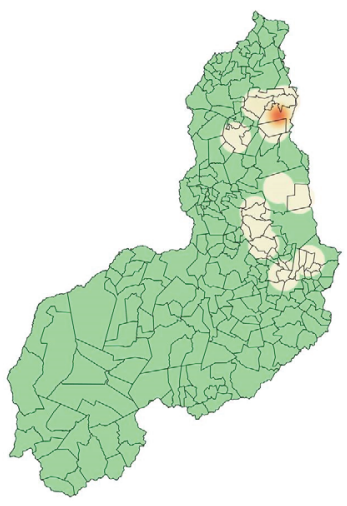

Rhodnius sp.

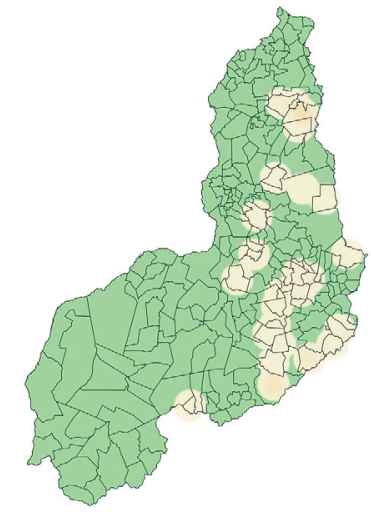

Panstrongylus sp. insects-2014-2017

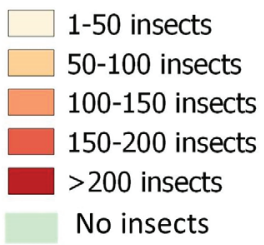

Figure 4 - Geographical distribution of triatomine species in Piaui State from 2014 to 2017.

in the Southwest region. In relation to the capture sites, it was found that both, T. brasiliensis and T. pseudomaculata presented higher infection rates in nymphs captured inside houses and adults captured in the peridomicile, T. sordida in adults captured inside houses and nymphs in the peridomicile, Rhodnius spp. and Panstrongylus spp. in adults captured in the peridomicile.

\section{DISCUSSION}

The greatest challenge of Chagas disease control in Northeastern Brazil has been the fight against triatomines of which there are naturally occurring stocks, and the persistent vulnerability of houses to recolonization by these insects. The present study demonstrates that entomological surveillance activities, which are the basis of vector control, are performed only in some parts of the municipalities of Piaui State. Therefore, many municipalities did not generate entomological data on vectors of Chagas disease during the studied period, possibly due to the fact that not all triatomines were examined, and/or due to limitations in the microscopic observation of fresh feces and/or the inexperience of technicians ${ }^{33}$. Surveillance activities, carried out in the four regions of the State, showed the presence of triatomine species characteristic of the Northeastern region of Brazil, such as T. brasiliensis and T. pseudomaculata. Unfortunately, the identification data of Rhodnius spp. and Panstrongylus spp. were restricted to the genus by limitations in taxonomic identification. Triatoma sordida was also identified in some municipalities. Comparing the present study with the one carried out in 2010, it is evident that Triatoma brasiliensis and Triatoma pseudomaculata continue to be the most widely distributed species in Piaui State ${ }^{34}$.

Triatoma brasiliensis was the most frequently identified species, present in a large proportion of the municipalities 
Table 2 - Average number of triatomines at different stages of development and catch sites recorded in the regions of the Piaui State from 2014 to 2017.

\begin{tabular}{|c|c|c|c|c|c|c|c|c|}
\hline & \multicolumn{2}{|c|}{ Central-North } & \multicolumn{2}{|c|}{ North } & \multicolumn{2}{|c|}{ Southeast } & \multicolumn{2}{|c|}{ Southwest } \\
\hline & Mean & SD & Mean & SD & Mean & SD & Mean & SD \\
\hline \multicolumn{9}{|l|}{ Triatoma brasiliensis } \\
\hline Adults inside houses & 22.93 & 45.870 & 0.76 & 1.809 & 41.79 & 62.597 & 18.20 & 51.973 \\
\hline Nymphs inside houses & 7.80 & 12.830 & 0.44 & 1.417 & 16.92 & 25.394 & 5.24 & 13.706 \\
\hline Adults peridomestic & 14.80 & 30.282 & 1.20 & 3.819 & 17.74 & 27.928 & 9.50 & 28.692 \\
\hline Nymphs peridomestic & 40.49 & 88.933 & 1.92 & 4.983 & 43.85 & 72.975 & 18.57 & 49.927 \\
\hline \multicolumn{9}{|l|}{ Triatoma pseudomaculata } \\
\hline Adults inside houses & 42.94 & 90.218 & 10.08 & 32.328 & 4.14 & 10.387 & 10.86 & 26.642 \\
\hline Nymphs inside houses & 2.19 & 4.580 & 0.32 & 1.215 & 0.66 & 2.080 & 0.49 & 2.147 \\
\hline Adults peridomestic & 4.31 & 9.334 & 1.40 & 2.677 & 1.18 & 3.534 & 1.77 & 6.045 \\
\hline Nymphs peridomestic & 64.33 & 144.756 & 18.44 & 64.611 & 2.94 & 6.901 & 6.98 & 18.010 \\
\hline \multicolumn{9}{|l|}{ Triatoma sordida } \\
\hline Adults inside houses & 0.04 & 0.187 & 0.00 & 0.000 & 0.49 & 2.580 & 13.85 & 51.104 \\
\hline Nymphs inside houses & 0.00 & 0.000 & 0.00 & 0.000 & 0.04 & 0.308 & 0.53 & 2.008 \\
\hline Adults peridomestic & .24 & 1.147 & 0.00 & 0.000 & 0.05 & 0.338 & 0.81 & 2.630 \\
\hline Nymphs peridomestic & 0.07 & 0.460 & 0.00 & 0.000 & 0.12 & 0.591 & 8.24 & 27.267 \\
\hline \multicolumn{9}{|l|}{ Rhodnius sp. } \\
\hline Adults inside houses & 1.82 & 8.570 & 0.36 & 1.319 & 0.01 & 0.100 & 0.00 & 0.000 \\
\hline Nymphs inside houses & 0.04 & 0.187 & 0.00 & 0.000 & 0.00 & 0.000 & 0.00 & 0.000 \\
\hline Adults peridomestic & 0.40 & 1.318 & 0.60 & 2.217 & 0.01 & 0.100 & 0.00 & 0.000 \\
\hline Nymphs peridomestic & 1.23 & 6.314 & 0.12 & 0.600 & 0.00 & 0.000 & 0.00 & 0.000 \\
\hline \multicolumn{9}{|l|}{ Panstrongylus sp. } \\
\hline Adults inside houses & 0.38 & 1.361 & 0.12 & 0.600 & 0.16 & 0.639 & 0.15 & 1.251 \\
\hline Nymphs inside houses & 0.07 & 0.555 & 0.00 & 0.000 & 0.02 & 0.224 & 0.00 & 0.000 \\
\hline Adults peridomestic & 1.06 & 3.316 & 0.28 & 0.980 & 0.45 & 2.330 & 0.27 & 2.053 \\
\hline Nymphs peridomestic & 0.14 & 0.880 & 0.16 & 0.800 & 0.05 & 0.366 & 0.00 & 0.000 \\
\hline
\end{tabular}

of the Southeast, Southwest and Central North regions. In this study, the municipalities that registered the presence of $T$. brasiliensis are located mainly in the semi-arid Caatinga biome. T. brasiliensis is a typical species of this region ${ }^{35}$ and naturally inhabits the cracks of rocky outcrops in the semiarid landscape. The present study shows that $T$. brasiliensis colonizes the interior of houses and documents the presence of nymphs of this species inside households in several municipalities. It is very likely that municipalities in the semiarid region of Piaui State, which did not register surveillance activities, had a similar and hidden entomological framework.

Triatoma pseudomaculata was also collected in several semiarid municipalities, mainly in the Southeast, Southwest and Central North regions. This species is also an important vector of Chagas disease in the Northeastern region of Brazil, in the Caatinga biome, naturally inhabiting the bark of typical bushes in semiarid areas ${ }^{36}$. Surveillance data from Piaui State compiled here show T. pseudoaculata is colonizing households and the peridomestic environment in many municipalities.

Several species of the genus Rhodnius are important vectors of Chagas disease ${ }^{37}$. In a study carried out in 2010 in the State, $R$. neglectus occurred more frequently in the South (in areas of the cerrado biome), while $R$. nasutus occurred more frequently in the North of the State, in areas of Caatinga, babassu forests in Maranhao and restingas in the Northeast. R. pictipes and R. robustus occurred only in the extreme North of the State, with a colonization index equal to zero ${ }^{34}$. The species $R$. nasutus has a natural habitat in the palm tree Copernicia prunifera (carnauba), which is the main palm of semiarid areas ${ }^{38}$. In this study, it was demonstrated that triatomines of the genus Rhodnius were captured more frequently in the Central North region which 

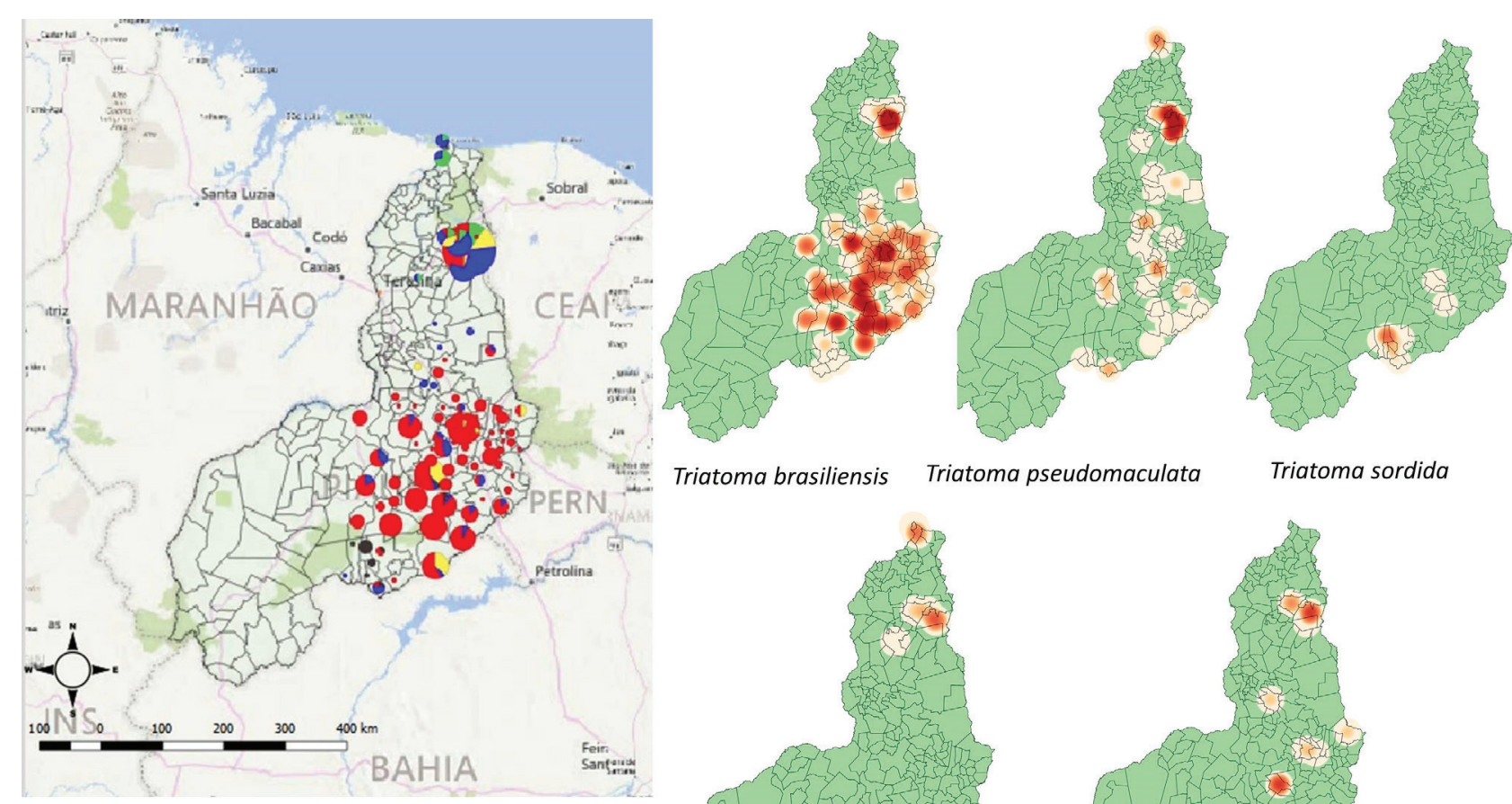

Triatoma brasiliensis Triatoma pseudomaculata Triatoma sordida

Triatoma brasiliensis

Triatoma pseudomaculata

Triatoma sordida

Panstrongylus sp.

Rhodnius sp.

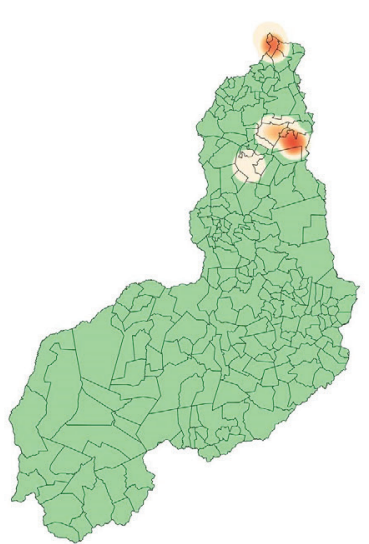

Rhodnius sp.

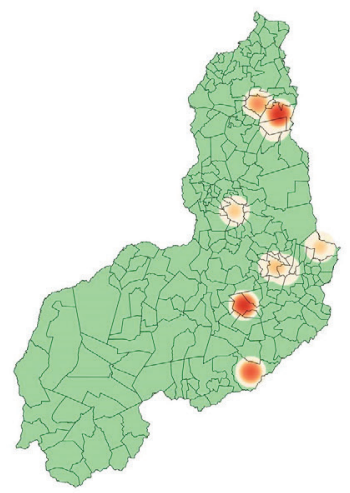

Panstrongylus sp.

infection-insects-2014-2017

No infected insects

1-2 infection insects

2-4 infection insects

4-8 infection insects

8-16 infection insects

$>16$ infection insects

No infected insects

Figure 5 - Geographic distribution of positive insects for trypanosomatids, distinguishing the different vector species of Chagas disease in Piaui State from 2014 to 2017.

contains the highest occurrence of carnauba and the natural resources of this palm tree are most frequently used by the population.

T. sordida had a particular distribution, being identified in the South of the State. This species has the Cerrado biome as its dispersion epicenter, but it can also be collected in the Cerrado-Caatinga ecotone and even in semiarid areas ${ }^{38}$. The highest average number of specimens per municipality was observed in the Southwest region of the State, where the Cerrado vegetation predominates, near the border with Tocantins State.

An important finding was the frequent presence of triatomines (including nymphal instar) inside residences in several municipalities, possibly constituting intradomiciliary colonies of insects feeding on the inhabitants. This finding points to a risk of persistent vector transmission in vast areas of Piaui State, with a preponderance of municipalities in the semiarid territories of the Southeast, Southwest and
Central North regions and of the species T. brasiliensis and T. pseudomaculata.

As reported above, the physiogeographic characteristics of these regions are extremely favorable to the presence of triatomine species typical of the semiarid territory and the Caatinga biome. In this way the process of colonization of the Northeastern outback, through cattle ranching and subsistence agriculture, was conducted on a territory where the triatomines naturally abound. The peculiar interaction between man and the environment in the semiarid region favors the contact of humans with insects that transmit Chagas disease. This interaction, over three centuries resulted in a stable transmission of T. cruzi and the occurrence of Chagas disease at endemic levels in the Brazilian Northeast outback.

Triatomines were successfully controlled by the use of insecticides between the 1970s and 2000s, with a significant reduction in transmission and prevalence 
Table 3 - Triatomine positivity rate for T. cruzi by region, species, stage and capture site in Piaui State from 2014 to 2017.

\begin{tabular}{|c|c|c|c|c|c|c|c|c|}
\hline & \multicolumn{2}{|c|}{ Central-North } & \multicolumn{2}{|r|}{ North } & \multicolumn{2}{|c|}{ Southeast } & \multicolumn{2}{|c|}{ Southwest } \\
\hline & $\mathrm{N}$ & Positive (\%) & $\mathrm{N}$ & Positive (\%) & $\mathrm{N}$ & Positive (\%) & $\mathrm{N}$ & Positive (\%) \\
\hline \multicolumn{9}{|l|}{ Triatoma brasiliensis } \\
\hline Adults inside houses & 1,970 & $9(0.5 \%)$ & 19 & $0(0.0 \%)$ & 9,297 & $115(1.2 \%)$ & 2,633 & $17(0.6 \%)$ \\
\hline Nymphs inside houses & 664 & $4(0.6 \%)$ & 24 & $0(0.0 \%)$ & 3,645 & $26(0.7 \%)$ & 775 & $5(0.6 \%)$ \\
\hline Adults in peridomestic areas & 1,267 & $32(2.5 \%)$ & 57 & $1(1.8 \%)$ & 3,817 & $68(1.8 \%)$ & 1,410 & $16(1.1 \%)$ \\
\hline Nymphs in peridomestic areas & 3,489 & $12(0.3 \%)$ & 48 & $0(0.0 \%)$ & 9,890 & $50(0.5 \%)$ & 2,606 & $7(0.3 \%)$ \\
\hline \multicolumn{9}{|l|}{ Triatoma pseudomaculata } \\
\hline Adults inside houses & 3,758 & $35(0.9 \%)$ & 252 & $3(1.2 \%)$ & 1,037 & $6(0.6 \%)$ & 1,817 & $5(0.3 \%)$ \\
\hline Nymphs inside houses & 192 & $1(0.5 \%)$ & 9 & $0(0.0 \%)$ & 140 & $0(0.0 \%)$ & 70 & $0(0.0 \%)$ \\
\hline Adults in peridomestic areas & 377 & $3(0.8 \%)$ & 55 & $6(10.9 \%)$ & 260 & $6(2.3 \%)$ & 253 & $3(1.2 \%)$ \\
\hline Nymphs in peridomestic areas & 5,533 & $21(0.4 \%)$ & 461 & $0(0.0 \%)$ & 729 & $2(0.3 \%)$ & 1,212 & $2(0.2 \%)$ \\
\hline \multicolumn{9}{|l|}{ Triatoma sordida } \\
\hline Adults inside houses & 3 & $0(0.0 \%)$ & 0 & $0(0.0 \%)$ & 112 & $1(0.9 \%)$ & 2,113 & $8(0.4 \%)$ \\
\hline Nymphs inside houses & 0 & $0(0.0 \%)$ & 0 & $0(0.0 \%)$ & 7 & $0(0.0 \%)$ & 70 & $0(0.0 \%)$ \\
\hline Adults in peridomestic areas & 20 & $0(0.0 \%)$ & 0 & $0(0.0 \%)$ & 10 & $1(10 \%)$ & 110 & $0(0.0 \%)$ \\
\hline Nymphs in peridomestic areas & 6 & $0(0.0 \%)$ & 0 & $0(0.0 \%)$ & 29 & $0(0.0 \%)$ & 1,214 & $4(0.3 \%)$ \\
\hline \multicolumn{9}{|l|}{ Rhodnius sp. } \\
\hline Adults inside houses & 153 & $8(5.3 \%)$ & 9 & $1(11.1 \%)$ & 2 & $0(0.0 \%)$ & 0 & $0(0.0 \%)$ \\
\hline Nymphs inside houses & 3 & $0(0.0 \%)$ & 0 & $0(0.0 \%)$ & 0 & $0(0.0 \%)$ & 0 & $0(0.0 \%)$ \\
\hline Adults in peridomestic areas & 34 & $2(5.9 \%)$ & 26 & $7(26.9 \%)$ & 3 & $0(0.0 \%)$ & 0 & $0(0.0 \%)$ \\
\hline Nymphs in peridomestic areas & 103 & $0(0.0 \%)$ & 3 & $0(0.0 \%)$ & 0 & $0(0.0 \%)$ & 0 & $0(0.0 \%)$ \\
\hline \multicolumn{9}{|l|}{ Panstrongylus sp. } \\
\hline Adults inside houses & 32 & $1(3.1 \%)$ & 3 & $0(0.0 \%)$ & 36 & $0(0.0 \%)$ & 19 & $4(21 \%)$ \\
\hline Nymphs inside houses & 6 & $0(0.0 \%)$ & 0 & $0(0.0 \%)$ & 4 & $0(0.0 \%)$ & 0 & $0(0.0 \%)$ \\
\hline Adults in peridomestic areas & 89 & $12(13.4 \%)$ & 7 & $4(57.1 \%)$ & 93 & $15(16.1 \%)$ & 36 & $3(8.3 \%)$ \\
\hline Nymphs in peridomestic areas & 12 & $0(0.0)$ & 4 & $0(0.0 \%)$ & 9 & $0(0.0 \%)$ & 0 & $0(0.0 \%)$ \\
\hline
\end{tabular}

of Chagas disease ${ }^{39}$. This control policy resulted in the virtual elimination of vector transmission in many areas in Brazil ${ }^{40}$. However, in vast regions of the Northeast, as in many municipalities of Piaui, the actions were discontinued, and the efforts directed to the control of mosquitoes which transmit arboviruses. The strong pressure that the natural environment exerts on human communities in relation to triatomines does not allow the interruption of entomological surveillance activities of Chagas disease and represents a risk of vector transmission of the disease reappearing, particularly in the Brazilian semi-arid region.

\section{ACKNOWLEDGMENTS}

The authors would like to thank the local entomological surveillance technicians from Piaui State.

\section{FINANCIAL SUPPORT}

This study was supported by the Oswaldo Cruz Foundation (Fiocruz). Entomological surveillance data were generated by the Health Secretariat of the Piaui State, Brazil.

\section{REFERENCES}

1. Justi SA, Galvão C. The evolutionary origin of diversity in Chagas disease vectors. Trends Parasitol. 2017;33:42-52.

2. Abad-Franch F, Lima MM, Sarquis O, Gurgel-Gonçalves R, Sánchez-Martín M, Calzada J, et al. On palms, bugs, and Chagas disease in the Americas. Acta Trop. 2015;151:126-41.

3. Santos SM, Sousa DM, Santos JP, Vieira JF, Gonçalves TC, Santos-Mallet JR, et al. Entomological survey in the state of Piaui, Northeastern Brazil, reveals intradomiciliary 
colonization of Triatoma brasiliensis macromelasoma. Rev Inst Med Trop Sao Paulo. 2017;59:e27.

4. Parente CC, Bezerra FS, Parente PI, Dias-Neto RV, Xavier $\mathrm{SC}$, Ramos AN, et al. Community-based entomological surveillance reveals urban foci of Chagas disease vectors in Sobral, State of Ceará, Northeastern Brazil. PLoS One. 2017;12:e0170278.

5. Sangenis LH, Saraiva RM, Georg I, Castro L, Santos Lima VS, Roque AL, et al. Autochthonous transmission of Chagas disease in Rio de Janeiro State, Brazil: a clinical and ecoepidemiological study. BMC Infect Dis. 2015;15:4.

6. Sarquis O, Carvalho-Costa FA, Toma HK, Georg I, Burgoa MR, Lima MM. Eco-epidemiology of Chagas disease in northeastern Brazil: Triatoma brasiliensis, T. pseudomaculata and Rhodnius nasutus in the sylvatic, peridomestic and domestic environments. Parasitol Res. 2012;110:1481-5.

7. Fe NF, França MS, Carvalho-Costa FA. Reassessing the entomological investigation around the first autochthonous case of Chagas disease in Western Brazilian Amazon. Mem Inst Oswaldo Cruz. 2009;104:121-3.

8. Lopez PM, Abrahan LB, Ralph MR, Valentinuzzi VS. Circadian system responses to nocturnal and diurnal hosts in the kissing bug, Triatoma infestans. Chronobiol Int. 2018;35: 1402-12.

9. Dumonteil E, Ramirez-Sierra MJ, Pérez-Carrillo S, TehPoot C, Herrera C, Gourbiere S, et al. Detailed ecological associations of triatomines revealed by metabarcoding and next-generation sequencing: implications for triatomine behavior and Trypanosoma cruzi transmission cycles. Sci Rep. 2018;8:4140.

10. Escandón-Vargas K, Muñoz-Zuluaga CA, Salazar L. Alimentación de Rhodnius prolixus. Biomedica. 2017;37:299-302.

11. Sant'Anna MR, Soares AC, Araujo RN, Gontijo NF, Pereira MH. Triatomines (Hemiptera, Reduviidae) blood intake: physical constraints and biological adaptations. J Insect Physiol. 2017;97:20-6.

12. Schofield CJ, Dias JC. The Southern Cone Initiative against Chagas disease. Adv Parasitol. 1999;42:1-27.

13. Ferreira IL, Silva TP. Eliminação da transmissão da doença de Chagas pelo Triatoma infestans no Brasil: um fato histórico. Rev Soc Bras Med Trop. 2006;39:507-9.

14. Silveira AC, Dias JC. O controle da transmissão vetorial. Rev Soc Bras Med Trop. 2011;44 Suppl 2:52-63.

15. Dias JC. Southern Cone Initiative for the elimination of domestic populations of Triatoma infestans and the interruption of transfusional Chagas disease. Historical aspects, present situation, and perspectives. Mem Inst Oswaldo Cruz. 2007;102 Suppl 1:11-8.

16. Dias JC, Prata A, Correia D. Problems and perspectives for Chagas disease control: in search of a realistic analysis. Rev Soc Bras Med Trop. 2008;41:193-6.
17. Dias JC, Machado EM, Fernandes AL, Vinhaes MC. Esboço geral e perspectivas da doença de Chagas no Nordeste do Brasil. Cad Saude Publica. 2000;16 Suppl 2:13-34.

18. Neiva A, Penna B. Viagem científica pelo norte da Bahia, sudoeste de Pernambuco, sul do Piauí e norte do sul de Goiás. Mem Inst Oswaldo Cruz. 1916;8:74-224.

19. Figueiredo PZ, Lima FG, Nunes JN. Doença de Chagas: primeiros casos autóctones no Estado do Piauí. Rev Soc Bras Med Trop. 1975;9:105-7.

20. Camargo ME, Silva GR, Castilho EA, Silveira AC. Inquérito sorológico da prevalencia de infecção chagásica no Brasil, 1975/1980. Rev Inst Med Trop Sao Paulo. 1984;26:192-204.

21. Coura JR, Abreu LL, Dubois LE, Lima FC, Arruda Jr ER, Willcox HP, et al. Morbidade da doença de Chagas. II Estudos seccionais em quatro áreas de campo no Brasil. Mem Inst Oswaldo Cruz. 1984;79:101-24.

22. Pinto AS, Bento DN. A palmeira Copernicia cerifera (Carnaúba) como ecótopo de Rhodnius nasutus em áreas rurais do estado do Piauí, Nordeste do Brasil. Rev Soc Bras Med Trop. 1986;19:243-5.

23. Bento DN, Freitas M, Pinto AS. Epidemiologia da doença de Chagas nos municípios de Castelo do Piauí e Pedro II, Estado do Piauí, Brasil. Rev Soc Bras Med Trop. 1989;22:73-9.

24. Bento DN, Farias LM, Godoy MF, Araújo JF. Epidemiologia da doença de Chagas na zona rural do município de TeresinaPiauí, Brasil. Rev Soc Bras Med Trop. 1992;25:51-8.

25. Borges-Pereira J, Castro JA, Campos JH, Nogueira JS, Zauza PL, Marques P, et al. Estudo de infecção e morbidade da doença de Chagas no município de João Costa - Parque Nacional Serra da Capivara, Piauí, Brasil. Rev Soc Bras Med Trop. 2002;35:31522.

26. Herrera L, D’Andrea PS, Xavier SC, Mangia RH, Fernandes O, Jansen AM. Trypanosoma cruzi infection in wild mammals of the National Park 'Serra da Capivara' and its surroundings (Piaui, Brazil), an area endemic for Chagas disease. Trans R Soc Trop Med Hyg. 2005;99:379-88.

27. Silveira AC, Vinhaes M. Doença de Chagas: aspectos epidemiológicos e de controle. Rev Soc Bras Med Trop. 1998;31 Suppl 2:15-60.

28. Borges-Pereira J, Castro JA, Silva AG, Zauza PL, Bulhões TP, Gonçalves ME, et al. Soroprevalência da infecção chagásica no Estado do Piauí, 2002. Rev Soc Bras Med Trop. 2006;39:530-9.

29. Instituto Brasileiro de Geografia e Estatística. Brasil/Piauí. [cited 2020 Jul 21]. Available from: https://cidades.ibge.gov.br/brasil/ pi/panorama

30. Araújo EL, Castro CC, Albuquerque UP. Dynamics of Brazilian caatinga: a review concerning the plants, environment and people. Functional Ecosys Communities. 2017;1:15-29.

31. Santos-Filho FS, Almeida Jr EB, Soares CJ. Cocais: zona ecotonal natural ou artificial? Rev Equador (UFPI). 2013;1:2-13 
32. World Health Organization Expert Committee on the Control of Chagas Disease. Control of Chagas disease: second report of the WHO Expert Committee. Geneva: WHO; 2002.

33. Vinhaes MC, Oliveira SV, Reis PO, Lacerda Sousa AC, Silva RA, Obara MT, et al. Assessing the vulnerability of Brazilian municipalities to the vectorial transmission of Trypanosoma cruzi using multi-criteria decision analysis. Acta Trop. 2014;137:105-10.

34. Gurgel-Gonçalves R, Pereira FC, Lima IP, Cavalcante RR. Distribuição geográfica, infestação domiciliar e infecção natural de triatomíneos (Hemiptera: Reduviidae) no estado do Piauí, Brasil, em 2008. Rev Pan-Amaz Saude. 2010;1:57-64.

35. Bezerra CM, Barbosa SE, Souza RC, Barezani CP, Gürtler RE, Ramos AN, et al. Triatoma brasiliensis Neiva, 1911: food sources and diversity of Trypanosoma cruzi in wild and artificial environments of the semiarid region of Ceará, northeastern Brazil. Parasit Vectors. 2018;11:642.

36. Freitas SP, Freitas AL, Prazeres SM, Gonçalves TC. Influência de hábitos antrópicos na dispersão de Triatoma pseudomaculata
Corrêa \& Espínola, 1964, através de Mimosa tenuiflora (Willdenow)(Mimosaceae) no Estado do Ceará, Brasil. Cad Saude Publica. 2004;20:333-6.

37. Massaro DC, Rezende DS, Camargo LM. Estudo da fauna de triatomíneos e da ocorrência de doença de Chagas em Monte Negro, Rondônia, Brasil. Rev Bras Epidemiol. 2008;11:22840.

38. Lima MM, Coutinho CF, Gomes TF, Oliveira TG, Duarte R, Borges-Pereira J, et al. Risk presented by Copernicia prunifera palm trees in the Rhodnius nasutus distribution in a Chagas disease-endemic area of the Brazilian northeast. Am J Trop Med Hyg. 2008;79:750-4.

39. Dias JC. A doença de Chagas e seu controle na América Latina: uma análise de possibilidades. Cad Saude Publica. 1993;9:2019.

40. Salvatella R, Irabedra P, Castellanos LG. Interruption of vector transmission by native vectors and "the art of the possible". Mem Inst Oswaldo Cruz. 2014;109:122-5. 
Spatial distribution of synanthropic triatomines in Piaui State, Northeastern Brazil 